\title{
Exploring Register Variation in Korean Popular Music (K-Pop)
}

\author{
Asfi Aniuranti \\ English Language Teaching Department, Universitas Nahdlatul Ulama Purwokerto, Indonesia \\ a.aniuranti@unupurwokerto.ac.id
}

\begin{tabular}{|c|c|}
\hline Article Info & ABSTRACT \\
\hline $\begin{array}{l}\text { Article History } \\
\text { - Article Received } \\
22^{\text {nd }} \text { July } 2019 \\
\text { - Article Reviewed } \\
25^{\text {th }} \text { September } 2019 \\
\text { - Article Accepted } \\
9^{\text {th }} \text { October } 2019 \\
\text { Keywords } \\
\text { register } \\
\text { English terms } \\
\text { Korean Popular Music } \\
\text { (K-Pop) }\end{array}$ & $\begin{array}{l}\text { Register is an interesting part of language varieties examined in sociolinguistics. This } \\
\text { study investigates one of register features namely English terms in Korean Popular } \\
\text { Music (K-Pop). The topic is chosen due to the high number of English terms (at } \\
\text { least } 105 \text { terms) and the difficulties in understanding their meanings. The objectives } \\
\text { of this study are (1) describing the form of the terms, (2) describing the formation } \\
\text { of the terms, and (3) explaining the specificity of the meanings. This study was } \\
\text { conducted through several phases called data gathering, data analysis and } \\
\text { presentation of data analysis. Overall, the results reveal several prominent findings. } \\
\text { First, most of the terms are in a form of words, meanwhile, the terms in phrases are } \\
\text { limited. Second, there are several types of term manufacturing, and the most } \\
\text { dominant one is compounding. Third, most of the terms' meanings have been } \\
\text { changed from the meanings on the dictionary, and they are classified as semantic } \\
\text { narrowing. }\end{array}$ \\
\hline
\end{tabular}

\section{INTRODUCTION}

Sociolinguistics which discusses language and society has always been an interesting branch of linguistics. One of the essential topics examined in sociolinguistics is language varieties including register. According to Holmes[1], register is the language of groups of people with common interests or jobs or the language used in situations associated with such group. He adds that over time the language of such groups develops more and more characteristics lexical, syntactic and even phonological. In conclusion, register is a special language used by people in a certain job, and it commonly has particular features on lexical, syntactic or even phonological.

One of the absorbing register cases which recently arises is English terms in Korean Popular Music (KPop). Leung[2] states that K-Pop is a musical genre that combines a variety of styles including pop, bip-bop, rap, rock, R\&B, and electronic music. Nowadays, South Korean popular music is drawing international attention. Lie[3] points out that the popularity of South Korean popular music has spread from neighbouring Asian countries, such as Japan and Taiwan, to farther ashore in Europe, the Americas, and the Middle East.

The growth of Korean popular music is accompanied by the emergence of specific terms used by the singers and the fans of K-Pop. The terms are generally in Korean, English, or combination between English and Korean, and in this research, the analysis is concentrated on English terms. The appearance of English terms in K-Pop industry is assumed due to the status of English as an international language and the weightiness of English in South Korea itself.

English terms in K-Pop are chosen due to two reasons. The first is the high number of English terms (at least 105 terms). The second is the difficulties in understanding the meanings only by consulting the dictionary. Here are the examples of the terms. 
(1) I'm YG stan but i respect SM artist, why? Because they are totally different from each other, we just can't compare them.

(2) Oh my god i just saw this! I can't say how happy I am right now! This song fits the moment so well. They're so cute, I ship them and I hope they will date for real someday.

In datum (1), there is a term called stan. This word has not been listed on the dictionary yet since it is a blending word between stalker and fan. On the dictionary written by Hornby[4], stalker means 'a person who follows or watches another person over a long period of time in a way that is annoying or frightening', and fan means 'a person who admire somebody/something or enjoy watching or listening to somebody or something very much'. In short, stalker fan / stan has a negative connotation on the dictionary. In K-Pop, the word stan has a positive and specific meaning. The term is used to call 'a fan of a music agency because she/he likes most of the singers from that agency'. This term does not have any negative connotations.

In datum (2), there is a term called ship. This term means 'supporting an unreal couple of singers so that they can be a real couple or supporting a friendship of singers'. For people who do know about K-Pop, this meaning might be confusing since the word ship on the dictionary written by Hornby[4] means 'to send or transport somebody or something by ship or by another means of transport'. There is completely no relation.

In K-Pop, the term ship is derived from the words relationship and friendship. On the dictionary written by Hornby[4], relationship means 'a loving and or sexual friendship between two people'; meanwhile friendship means 'a relationship between friends'. In K-Pop, suffix \{-ship\} which is normally used to form a noun is used to form a verb, and that verb has a special meaning.

The brief discussion of the previous examples shows an interesting fact found in K-Pop, and besides those two, there are still 103 other terms. In this study, English terms in K-Pop are analysed from several points of view. They are the form, the formation and the meanings of the terms. Through such a discussion, the result is expected to bring practical and theoretical benefits.

\section{LITERATURE REVIEW}

\section{a. Register}

Holmes[1] states that register tends to be associated with particular groups of people or sometimes specific situations of use. Journalese, baby-talk, legalese, the language of auctioneers, race-callers, and sports commentator, the language of air plane pilots, criminals, financiers, politicians and disk jockeys, the language of the courtroom and the classroom, could all be considered examples of different register. Romaine[5]; Halliday \& Hasan[6]; Mesthrie et al,[7] argue that register is a language variety based on the context in which the variety is employed. Meanwhile, Chaer \& Agustina[8] explain that register is connected with a language used for certain fields, for instance, literature, journalism, agriculture, shipping, economics, trading, education, etc. The variety in a certain field can be recognized from its lexicon, syntactic or even phonological features.

Based on the previous explanation, there are several substantial conclusions. Firstly, register might appear due to certain context in a certain field or a specific community. Secondly, register has several characteristics such as lexicon, syntactic or even phonological features.

\section{b. The Form of the Terms}

Hornby [4] accounts that a term is a word or phrase used as the name of something, especially one connected with a particular type of language. Kridalaksana[9] adds that a term is a word or combination of words that carefully uses a certain concept, process, situation or specific feature in a particular field. In short, a term might be in a form of word or phrase which shows the specificity of a particular field.

Kridalaksana[9] argues that a word is a morpheme or combination of morphemes which is considered by linguists as the smallest unit uttered freely. According to the number of morphemes, words can be classified into monomorphemic and polymorphemic words. $\mathrm{M}$ onomorphemic word is a word consists of one morpheme[10][12].Meanwhile, the polymorphemic word is a word consists of two morphemes or more [13][10][12].

Kridalaksana[9] says that a phrase is a combination of two words or more which is not predictive. According to Hornby [4], a phrase is a group of words 
without a finite verb, especially one that form part of a sentence.

\section{c. The Formation of the Terms}

Jackson[14] and Booij[13] argue that words in English can be formed through several processes such as blending, clipping, and acronym. Here is a brief explanation.

Blending is a combination of two words which still has the part of its basic words, for example, telegenic < television + photogenic; brunch $<$ breakfast + lunch and stagflation < stagnation + inflation. Clipping is a shortening process by cutting a word into one syllables or more, for example, fridge < refrigerator; exam < examination; mike $<$ microphone and demo < demonstration. Acronym is a shortening by combining the first font of each word, for example, UNESCO < United Nations Educational, Scientific and Cultural Organization and NATO $<$ North Atlantic Treaty Organization.

Besides those three ways, there are other ways of forming words in English. Jackson[14] says that English words can be formed through backformation, compounding, derivation, and conversion. Back-formation is a deletion of affixes. For instance: the word babysit (verb) is formed after the word babysitter (noun).

Compounding is a combination of two words or more to form a new word, for example, motorway which is formed by combining the word motor and way. Derivation is a process of adding affix (prefix and suffix). This process normally changes the word classes. For example: the word location is formed from locate and $\{-i o n\}$. Brinton $\&$ Brinton[15] add that derivation is a word-formation process by adding a derivational affix to the basic form.

Another process that belongs to derivation is conversion. Conversion is a process of word-class changing. For example, the words skin and bottle are nouns before they are used as verbs. Besides the previous word manufacturing, there is also alphapetism. Booij[13] points out that alphabetism is a combination of the first letters of words, pronounced with the phonetic value of these letters in the alphabet, for instance, CD 'compact disc', SMS 'Short Message Service'.

\section{d. Semantic Change}

\section{1) Widening}

Widening is a process of semantic change in which the meaning of a word becomes more general than its previous meaning [16][17][18]. Harley[17] gives an example of it. The word 'manage' used to mean specifically 'handle a horse,' but now it means handling anything difficult successfully.

\section{2) Narrowing}

Narrowing is a process of semantic change in which the meaning of a word becomes more specific than its previous meaning [16][17][18]. Harley[17] states that sometimes narrowing happens when another word with a similar meaning comes along and takes over the meaning of the original. This is the case of the word deer, which in Old English meant 'animal'.

\section{3) Amelioration}

Amelioration is a process of semantic change in which a word moves from a lower register to a higher register or from having negative connotations to have positive connotations. Harley[17] gives an example. The word nice has undergone amelioration; it used to have the negative meaning "stupid, simple," and now, of course, it means "nice.".

\section{4) Pejoration}

Harley[17] states that Pejoration is what happens when a word moves downward, socially or emotionally. We saw that bully used to have a positive meaning, 'sweetheart, lover,' and we know that it now means 'abusive person'.

\section{5) Metaphor}

According to Keraf[16], metaphor is a semantic change due to the similar feature of two objects. It is a semantic change based on the similarity of meaning perception.

\section{6) Metonymy}

According to Keraf[16], metonymy is a process of semantic change which emerges due to the closeness among the words in certain semantic relation and can be classified according to place or time, the relation between content and surface, cause and effect relation. 


\section{7) Combination of several types}

According to Stockwell \& Minkova[19], most of the semantic change of words can be classified into several categories. For example, the word vixen is the usage of figurative (widening analogy). The previous meaning of this word is 'female fox', and now it is used to call 'male or female fox'. This word is also used to call other creatures like a human.

\section{8) Semantic shift}

According to O'Grady, et al[18], semantic shift is a process where a word loses its old meaning and has a new meaning which is related sometimes. For example, the word bead formerly means 'prayer', and now it means 'rosary'. Besides, semantic shift can also be defined as a process in which the new meaning of a new word is irrelevant to its old meaning. For instance: the word guy means 'cheerful, happy', and now it means 'homosexual'.

\section{METHODOLOGY}

The data of this research were gathered through several phases. The term list was obtained from the articles written by Kikawai[20] and Acton[11]. To find out the terms which have not been listed, the researcher interviewed three fans of Korean popular music via Facebook. Then, to obtain the empirical data, the researcher searched the usage of each term on three sources, news articles of Korean popular music at wnw.soompicom, fan comments left on YouTube, and conversation between the researcher and a Korean popular music fan via Black Berry Messenger (BBM). All of the data then were elaborated by considering several relevant theories. The results were presented through words and tables.

\section{RESULT AND DISCUSSION}

\section{a. The Form of the Terms}

English terms in Korean popular music can be classified into words and phrases. The terms in word can be categorized into monomorphemic and polimorphemic words. Moreover, based on the word classes, the terms can be grouped into nouns, verbs, and adjectives; meanwhile, the terms in the form of phrases are noun phrases. Here is a brief explanation.

In Korean popular music, there are terms in the form of monomorphemic words since those terms consist of one morpheme, for instance, $i d o l$. This means 'Korean singers'. It consists of one morpheme or cannot be split up into the smaller meaningful unit. In K-Pop, the term $i d o l$ is often shortened to dol. This is normally mixed with other words to give special titles for the singers, for example, fashionistadol 'Korean singers who have a good sense of fashion'.

Besides monomorphemic words, almost all terms are in polymorphemic form, for example, idolization 'the singers' physical changes which make them more appropriate to be a singer' and chocolate abs 'male singers' abdominals which has the same form as chocolate bar'. Those terms are polymorphemic words as the two consist of several morphemes.

In K-Pop, there are also several terms in a special form. They can be grouped into shortening, blending, and a combination between font and word, e.g. fan sign, PV, selca, and S-line. Then, based on the word classes, English terms in Korean popular music can be classified into nouns, verbs, and adjectives, e.g. visual (noun), ship, fangirl, and fanboy (verb), and shipping (adjective). In Korean popular music, there are, besides, some terms in phrases and they belong to noun phrases as the head of those phrases are nouns.

\section{b. The formation of the terms}

\section{1) Words}

In K-Pop, the terms in form of words are formed through several processes namely derivation, conversion, compounding, blending, clipping, initialism/alphabetisms, back-formation, and a combination between font and word or number and word. The most dominant process which emerges is compounding, for instance, chocolate abs. In K-Pop, this term means 'abdominals of male singers in K-Pop which is shaped like chocolate bar'. In this term, abs is a clipping word or abdominals. The shape of a chocolate bar is used to describe the abdominals of male singers in K-Pop. Other terms that are formed with compounding are bagel girl, bagel boy, milky skin, porcelain skin, eye-smile, gummy smile, honey thighs, monster rookie, idol group, girl group, boy group, etc.

\section{2) Phrase}

In K-Pop, at least there are four terms in the form of phrase. They are main vocalist'main vocal in a boy/girl group', main dancer 'main dancer in a boy/girl group', main rapper 'main rapper of a boy/girl group', and full album 'a music album consists of 10 to 12 songs or more'. All those terms are noun phrases 
formed with pre-modifier + noun. All the pre-modifiers are adjectives.

\section{c. The Meaning of the terms}

In this study, each term meaning is compared to the dictionary meaning to find out its specificity. Several terms in K-Pop have the same meaning with the dictionary meaning. This similarity might emerge since the dictionary employed has already listed many terms from many different fields including music in general, for an example album. In the dictionary written by Hornby [8], album means 'a collection of pieces of music released as single item, usually on $\mathrm{CD}$, cassette, or on the internet'. This meaning is similar to the meaning of album in Korean popular music.

Even though several terms have the same meanings with dictionary meaning, most of the terms have different meanings from the dictionary. The semantic changes can be classified into broadening, narrowing, amelioration, metaphor, mix types, and semantic shift. Here is a brief explanation.

In Korean popular music, there are several meanings of the terms that have been broadened from the dictionary meaning, for example, single/track. Pay attention to the following datum.

(1) Jay Park will be cooling the hot summer nights as he releases his latest single, "Na Na" on July 25. The song, "Na Na," which conjures images of partying to cool off on hot summer nights, is an impressive song that has an addictive hook that is easy to follow.

It is the product of a trusted collaboration between Jay Park and his best bud Cha Cha Malone who cocomposed the track. The lyrics, on the other hand, are co-written by Jay Park and AOMG rapper LOCO.

On the dictionary written by Hornby [8], track means 'a piece of music or song on a record, tape, or CD', and single means 'a piece of recorded music, usually popular music, that consists of one song; a CD that a single is recorded on'. Based on the dictionary meaning, it can be concluded that track and single mean song, but they are used in a different context. The word track is used to call a song in an album, but single is used to call a song released alone. This difference does not appear in Korean popular music. The meanings of Track and single are enlarged. The two are used to call 'a song in an album or a song that is released alone'. Those two terms are a synonym. It can be seen from the datum above, a song entitled $\mathrm{Na} N a$ is called as a single as well as a track.

The most dominant semantic change in Korean popular music is narrowing. Pay attention to the following datum.

(2) 5-member boy group 100\% dropped the music video for title track "U Beauty" off of its cool summer album "Sunkiss." The group already started its promotion for the album on the main three broadcast stations, showing off their improved vocal and dance skills.

On the dictionary written by Hornby [8], boy means 'a male child or a young man person', and group means 'several musicians who perform together, especially to play pop music'. It can be concluded that boy group means 'a group of male singers'. In Korean popular music, boy group has a specific meaning. It is only used to call 'a male group that sings and dances in their performances or a male group with singing and dancing concept'. In datum (4), boy group is used to call a group named $100 \%$. They are called as a boy group since they have the ability in singing and dancing.

There is also semantic change that can be classified as amelioration. The example is monster rookie. Based on the dictionary, this term has a negative connotation, but in Korean popular music, it means 'a new singer who has a great achievement in music industry'. There is completely no negative connotation.

Another type of semantic change in Korean popular music is a metaphor. One of the examples of this type is porcelain skin. Based on the dictionary meaning, this term means 'skin from porcelain', but through metaphor, the meaning of this term has changed. It means 'skin that is sparkling and flawless'.

In K-Pop, several terms can be classified as a mixed type. The mixed types that appear are narrowing amelioration, metaphor narrowing, metaphor pejoration, and metonymy narrowing. Besides the mixed type, there is also semantic shift.

\section{V.CONCLUSION}

In this study, English terms in K-Pop are analyzed from three points of view namely form, formation and meaning. The results show several findings. First, most of the terms are in a form of words, meanwhile, the terms in phrases are limited. Second, there are 
several types of term manufacturing, and the most dominant is compounding. Third, most of the meanings of the terms have been changed from the meaning in the dictionary, and most of them are classified into semantic narrowing.

\section{REFERENCES}

[1] Holmes, J. (1992). An Introduction to sociolinguistics. London: Longman.

[2] Leung, S. (2012). Catching the k-pop wave: Globality in the production, distribution, and consumption of South Korean popular music (Thesis). Retrieved from http://digitalwindow.vassar.edu/cgi/viewconten t.cgi?article $=1151 \&$ context $=$ senior_capstone

[3] Lie, L. (2012). 'What is the $\mathrm{k}$ in k-pop? South Korean popular music, the culture

industry, and national identity', Korea Observer, 43(3). Retrieved from http://www.tobiashubinette.se/hallyu_1.pdf.

[4] Hornby. (2010). Oxford advanced learner's dictionary. Oxford: Oxford University Press.

[5] Romaine, S. (1994). Language in society: An introduction in sociolinguistics. Oxford: Oxford University Press.

[6] Halliday, M.A.K. \& Hasan, R. (1994 [1985]). Bahasa, Konteks, dan Teks: Aspek-aspek Bahasa dalam Pandangan Semiotik Sosial (Asruddin Barori Tou, Trans.). Yogyakarta: Gadjah Mada University Press.

[7] Mesthrie, R., Swann, J., Deumert, A., \& Leap, W.L. (2000). An Introduction to Sociolinguistics, Edinburgh: Edinburgh University Press.

[8] Chaer, A. \& Agustina, L. (2010). Sosiolinguistik: Perkenalan awal. Jakarta: Rineka Cipta.

[9] Kridalaksana, H. (2011). Kamus linguistik. Jakarta: PT Gramedia Pustaka Utama.

[10] Wijana, I.D.P. (2009). Berkenalan dengan Linguistik. Yogyakarta: Pustaka Araska.

[11] Acton, D. (2013). 101 Korean Pop Culture Words You Absolutely Must Know. Retrieved from http://www.dramafever.com/news/101-koreanpop-culture-words-you-absolutely-must-know/

[12] Verhaar, J.W.M. (2010). Asas-asas linguistik umum. Yogyakarta: Gadjah Mada University Press.

[13] Booij, G. (2007). The grammar of word: An introduction to morphology. Oxford: Oxford University Press.
[14] Jackson, H. (1988). Words and their meaning: learning about language. New York: Addison Wesley Longman Inc.

[15] Brinton, L.J. \& Brinton, D.M. (2010). The linguistic structure of modern English. Amsterdam: John Benjamins Publishing Company.

[16] Keraf, G. (1985). Diksi dan gaya bahasa. Jakarta: PT Gramedia.

[17] Harley, H. (2006). English words: A linguistic introduction. Oxford: Blackwell Publishing Ltd.

[18] O'Grady, W., Archibald, J., Aronoff, M., \& ReesMiller, J. (2009). Contemporary linguistics: An introduction. Boston: Bedford/St. Martin's.

[19] Stockwell, R. \& Minkova, D. (2003). English words: bistory and structure. Cambridge: Cambridge University Press.

[20] Kikawai. (2012). Glosarium (Daftar Istilab2 Asing) yang Sering Kita Gunakan di Dunia K-Pop. Retrieved from

http://yeppopo.wordpress.com/2012/01/28/in termezo-glosarium-daftar-istilah2-asing-yangsering-kita-gunakan-di-dunia-k-pop/ 